No 4078

Studia nad Autorytaryzmem i Totalitaryzmem 43, nr 4 Wrocław 2021

https://doi.org/10.19195/2300-7249.43.4.33

\author{
PIOTR OCHMAN \\ ORCID: 0000-0001-5590-3299 \\ Uniwersytet Wrocławski \\ piotr.ochman@uwr.edu.pl
}

\title{
Kryminalizacja finansowania terroryzmu w świetle przepisu art. 165a kodeksu karnego. Część 1
}

Słowa kluczowe: terroryzm, finansowanie terroryzmu, akt terrorystyczny, działalność terrorystyczna, przestępczość grupowa.

\section{CRIMINALIZATION OF TERRORISM FINANCING IN THE POLISH CRIMINAL CODE} (ART. 165A). PART 1

\begin{abstract}
Progressing globalization, ease of movement and the pace of information flow undoubtedly have intensified the threat of an important social problem - terrorism. An key instrument of combating terrorist activity is counteracting its financing. This article will analyze the crime of financing terrorism, which has been typified in Art. 165a of the Polish Criminal Code. An attempt will be made to answer the question of whether the legislative measures taken in the above-mentioned scope are purposeful, necessary and justified. The genesis of the current legal regulations in the field of counteracting the financing of terrorism in the Polish penal code will be also presented.
\end{abstract}

Keywords: terrorism, financing terrorism, terrorist act, terrorist activity, group crime.

\section{Uwagi wprowadzające}

Postępujące procesy globalizacyjne, łatwość przepływu osób oraz tempo przepływu informacji niewątpliwie nasiliły zagrożenie istotnym problemem społecznym, jakim jest terroryzm. Fenomenologia współczesnego terroryzmu zakłada istnienie określonego audytorium, masowego odbiorcy (,widza”) bezprawnych 
działań, co bez wątpienia przekłada się na funkcjonowanie społeczeństw, w tym w perspektywie zagrożenia wiktymizacją ${ }^{1}$.

Według jednej z definicji terroryzm to

systematyczne stosowanie przymusowego zastraszania, zwykle w celu realizacji celów politycznych. Jest używany do tworzenia i wykorzystywania atmosfery strachu wśród szerszej grupy docelowej niż bezpośrednie ofiary przemocy oraz do nagłośnienia sprawy, jak również do zmuszenia celu do przyłączenia się do celów terrorystów² ${ }^{2}$.

Chodzi zatem o siłowe narzucenie ideologii, przekonań, religii czy też sposobu życia ${ }^{3}$. Z kolei zgodnie z definicją zawartą w Encyklopedii PWN przez terroryzm rozumie się

różnie umotywowane, najczęściej ideologicznie, planowane i zorganizowane działania pojedynczych osób lub grup, podejmowane $\mathrm{z}$ naruszeniem istniejącego prawa w celu wymuszenia od władz państwowych i społeczeństwa określonych zachowań i świadczeń, często naruszające dobra osób postronnych; działania te są realizowane $\mathrm{z}$ całą bezwzględnością, za pomocą różnych środków (nacisk psychiczny, przemoc fizyczna, użycie broni i ładunków wybuchowych), w warunkach specjalnie nadanego im rozgłosu i celowo wytworzonego w społeczeństwie lęku $u^{4}$.

Ważnym elementem wskazanego rozumienia tytułowego terminu jest komponent ideologiczny (wartościujący), który może być różnie definiowany w zależności od wyznawanych poglądów politycznych danego autora ${ }^{5}$. Z całą pewnością jest to też jedna z przyczyn niewypracowania jednej, akceptowanej przez wszystkich definicji pojęcia „terroryzm”, a także ustalenia ścisłych kryteriów pozwalających zakwalifikować dane zdarzenie jako akt terrorystyczny ${ }^{6}$. Jak słusznie się wskazuje, aktywność stanowiąca dla jednych wyraz walki o wolność, dla innych może być przejawem działalności terrorystycznej ${ }^{7}$ czy też nieposłuszeństwa obywatelskiego ${ }^{8}$. Nie oznacza to jednak, iż w literaturze naukowej problem definicji

1 W. Dadak, Terroryzm - nowe zagrożenie czy niedostrzegane wcześniej zjawisko? O problemach z definiowaniem i analiza przestępczości terrorystycznej, [w:] W poszukiwaniu prawdy. Rozważania o prawdzie, historii i sprawiedliwości. Prace dedykowane profesorowi Janowi Widackiemu, red. K. Banasik et al., Kraków 2018, s. 183.

2 P. Wilkinson, Terrorism versus Democracy: The Liberal State Sesponse, Abingdon 2005, s. $12-13$.

3 B. Hołyst, Terroryzm, t. 1, Warszawa 2000, s. 56.

4 https://encyklopedia.pwn.pl/szukaj/terroryzm.html (dostęp: 25.10.2021).

5 I. Resztak, Zjawisko terroryzmu, „Prokuratura i Prawo” 2012, nr 7-8, s. 149.

6 G.P. Fletcher, The Indefinable Concept of Terrorism, „Journal of International Criminal Justice” 4, 2006, nr 5, s. 900; J.P. Gibbs, Conceptualization of Terrorism, „American Sociological Review" 54, 1989, nr 3, s. 329; K. Indecki, Prawo karne wobec terroryzmu i aktu terrorystycznego, Łódź 1998, s. 23.

7 W. Dadak, op. cit., s. 185.

8 Por. P. Ochman, J. Baściuk, Niepostuszeństwo obywatelskie a polski system prawa karnego, [w:] Prawna działalność instytucji społeczeństwa obywatelskiego, red. J. Blicharz, J. Boć, Wrocław 2009, s. 735-754. 
terroryzmu jest pomijany, gdyż propozycji terminologicznych w tym zakresie jest ponad $100^{9}$. Podnosi się zwłaszcza, że — niezależnie od przyjmowanej perspektywy ideologicznej — definicja terroryzmu powinna uwzględniać osiem czynników związanych z tym pojęciem ${ }^{10}$ : element przemocy, rodzaj ofiar, powiązanie sprawcy z organizacją państwową, motyw działania, zorganizowanie i związek z przekonaniami ideologicznymi, działanie w celu osiągnięcia efektu patosu oraz nieodczuwanie poczucia winy. Zjawisku terroryzmu nieodłącznie towarzyszy także zamiar wywołania strachu lub lęku u potencjalnych ofiar ${ }^{11}$.

Według raportu Europolu na obszarze Unii Europejskiej w 2020 roku łącznie miało miejsce 57 ukończonych, nieudanych i udaremnionych ataków terrorystycznych, Wielka Brytania zgłosiła 62 incydenty o charakterze terrorystycznym, natomiast Szwajcaria - 212. W wyniku ataków terrorystycznych na obszarze UE zginęło aż 21 osób (54 zostały ranne), w Wielkiej Brytanii - 3, natomiast w Szwajcarii $-1^{13}$. Aresztowane w związku z popełnieniem przestępstw związanych z terroryzmem zostały 449 osoby, w tym na terenie Wielkiej Brytanii $185^{14}$. Jakkolwiek ilościowo mogłoby się wydawać, że liczby te nie są symptomem większego zagrożenia, to jednak biorąc pod uwagę potencjalną skalę i skutki ataków terrorystycznych, danych tych nie można bagatelizować ${ }^{15}$. Ataki terrorystyczne powodowane przez jednostki lub małe grupy przy wykorzystaniu nieskomplikowanych sposobów działania (na przykład dźgnięcie nożem) nie wydają się wymagać większych nakładów finansowych, w przypadku jednak działań zorientowanych na wykorzystanie broni palnej, materiałów wybuchowych czy też innych, bardziej wyrafinowanych metod działania potrzeby finansowe są znacznie większe. W tym wypadku organizacje terrorystyczne muszą także pokryć koszty utrzymania infrastruktury, rekrutacji, propagandy, zwiększania zdolności operacyjnych, co wymaga znacznych wydatków na szkolenia, wynagrodzenia, odszkodowania dla bliskich czy też logistykę ${ }^{16}$.

Pozyskiwanie środków na wskazane wyżej cele następuje z różnych źródeł. Mogą to być przykładowo: składki członkowskie, zbiórki, darowizny, zyski z działalności legalnie działających podmiotów bądź działalności niezgodnej z prawem ${ }^{17}$. Tak pozyskane środki, aby osiągnąc cel ich gromadzenia, muszą być następnie przetransferowane poza terytorium Europy. Wykorzystuje się w tym celu rozmaite kanały dystrybucji, takie jak przelewy bankowe, przekazy pieniężne

9 Zob. np. przegląd definicji w K. Indecki, op. cit., s. 18-24; W. Dadak, op. cit., s. 188-191; I. Resztak, op. cit., s. 150-152.

10 G.P. Fletcher, op. cit., s. 910.

11 W. Dadak, op. cit., s. 193.

12 Europol, European Union Terrorism Situation and Trend Report, Luxemburg 2021, s. 6.

13 Ibidem, s. 6.

14 Ibidem, s. 12.

15 W. Dadak, op. cit., s. 192.

16 Europol, op. cit., s. 31.

17 Ibidem, s. 31-32. 
za pośrednictwem wyspecjalizowanych pośredników (na przykład MoneyGram, Western Union), jak również przy wykorzystaniu tak zwanego systemu hawala ${ }^{18}$. W konsekwencji jednym z ważniejszych instrumentów zwalczania działalności terrorystycznej jest przeciwdziałanie jej finansowaniu. Okoliczność ta zresztą często pojawia się w pracach Organizacji Narodów Zjednoczonych, Unii Europejskiej oraz Rady Europy ${ }^{19}$.

W realiach społeczno-gospodarczych Rzeczypospolitej Polskiej problematyka finansowania działalności terrorystycznej może się wydawać nieco egzotycz$\mathrm{na}^{20}$. Wskazać jednak należy, że w 2020 roku w Polsce aż 9 osób zostało tymczasowo aresztowanych w związku z działalnością terrorystyczną ${ }^{21}$. Dodatkowo wszczęto 9 postępowań analitycznych w przedmiocie transakcji mogących mieć związek z finansowaniem terroryzmu, dotyczących transakcji przeprowadzanych przez osoby fizyczne pochodzące z krajów podwyższonego ryzyka terrorystycznego $^{22}$. We wskazanym okresie do Generalnego Inspektora Informacji Finansowej wpłynęło także 38 wniosków Agencji Bezpieczeństwa Wewnętrznego o udzielenie informacji o osobach i podmiotach, odnośnie do których zachodziło podejrzenie finansowania terroryzmu ${ }^{23}$. Tymczasem Generalny Inspektor Informacji Finansowej przekazał Agencji Bezpieczeństwa Wewnętrznego 11 informacji uzasadniających podejrzenie finansowania terroryzmu ${ }^{24}$. Prowadzone były ponadto 2 postępowania przygotowawcze dotyczące podejrzenia popełnienia przestępstwa finansowania działalności terrorystycznej z art. 165a kodeksu karnego ${ }^{25}$, natomiast w sądach powszechnych doszło do skierowania aktu oskarżenia w sprawie o przestępstwo finansowania terroryzmu, jak również nieprawomocnie skazano jedną osobę za przestępstwo finansowania terroryzmu ${ }^{26}$.

W konsekwencji pozornie obca krajowej rzeczywistości społecznej problematyka stanowi coraz większe zagrożenie. Rzeczpospolita Polska, uczestnicząc

18 Ibidem, s. 33.

19 S. Hoc, Kryminalizowanie finansowania terroryzmu, „Opolskie Studia Administracyjno-Prawne” 14, 2016, nr 1, s. 27. Zob. także E.M. Guzik-Makaruk, E. Zatyka, Rada Europy wobec terroryzmu - elementy strategii przeciwdziałania, „Białostockie Studia Prawnicze” 2009, z. 6, s. 48-56; R. Drzazga, Konwencje antyterrorystyczne ONZ - charakterystyka oraz zakres zobowiqzań natożonych na państwa-strony, [w:] Terroryzm. Materia ustawowa?, red. K. Indecki, P. Potejko, Warszawa 2009, s. 15-26; W. Filipkowski, Formy zwalczania terroryzmu na podstawie wybranych uregulowań Unii Europejskiej i NATO, [w:] Terroryzm. Materia..., s. 30-36; I. Resztak, Konwencje Rady Europy o przeciwdziałaniu zjawisku terroryzmu, „Prokuratura i Prawo” 2012, nr 10, s. 112-122.

20 Zob. S. Pikulski, Prawne środki zwalczania terroryzmu, Olsztyn 2000, s. 138.

21 Europol, op. cit., s. 15.

22 Sprawozdanie Generalnego Inspektora Informacji Finansowej z realizacji ustawy z dnia 1 marca 2018 roku o przeciwdziałaniu praniu pieniędzy oraz finansowaniu terroryzmu w 2020 roku, Warszawa 2021, s. 49-50.

23 Ibidem, s. 50.

24 Ibidem.

25 Ibidem.

26 Ibidem. 
w działaniach międzynarodowej koalicji antyterrorystycznej, może być także celem ewentualnych działań terrorystycznych ${ }^{27}$. Dlatego też zasadne staje się podejmowanie działań prewencyjnych zmierzających do ograniczenia zagrożeń w tym zakresie. Podstawę wskazanych działań stanowi prawny system przeciwdziałania terroryzmowi, uzupełniający pozostałe formy ochrony bezpieczeństwa wewnętrznego. Do prawnych instrumentów przeciwdziałania terroryzmowi należy zaliczyć zwłaszcza: ustawę z dnia 10 czerwca 2016 roku o działaniach antyterrorystycznych ${ }^{28}$, ustawę z dnia 1 marca 2018 roku o przeciwdziałaniu praniu pieniędzy i finansowaniu terroryzmu ${ }^{29}$, ustawę z dnia 26 kwietnia 2007 roku o zarządzaniu kryzysowym ${ }^{30}$, a także ustawę z dnia 6 czerwca 1997 roku — Kodeks karny $^{31}$, typizującą w szczególności przestępstwa terrorystyczne, zasady odpowiedzialności i zasady karania z tytułu ich popełnienia.

\section{Uwagi szczegółowe}

Analizując historię konwencji antyterrorystycznych, można zauważyć, że początki kryminalizacji terroryzmu dotyczyły konkretnych zachowań wyrządzających szkody, by następnie poszerzyć swój zasięg na różnego rodzaju formy wspierające takie zachowania, a następnie także ich finansowanie ${ }^{32}$. W doktrynie trafnie stwierdza się, że jakkolwiek zachowania o charakterze terrorystycznym

27 Uzasadnienie rządowego projektu ustawy o działaniach antyterrorystycznych oraz o zmianie niektórych innych ustaw, druk sejmowy $\mathrm{nr} 516, \mathrm{~s} .1$.

28 Dz.U. z 2019 r. poz. 796 z późn. zm. Określa ona zasady prowadzenia działań antyterrorystycznych oraz współpracy między organami właściwymi w zakresie prowadzenia tych działań. W ustawie tej zdefiniowano termin ,zdarzenie o charakterze terrorystycznym”, przez które należy rozumieć sytuację, co do której istnieje podejrzenie, że powstała na skutek przestępstwa o charakterze terrorystycznym, o którym mowa w art. $115 \S 20$ kodeksu karnego, lub zagrożenie zaistnienia takiego przestępstwa.

29 Dz.U. z 2021 r. poz. 1132 z późn. zm. Określa ona zasady i tryb przeciwdziałania praniu pieniędzy oraz finansowaniu terroryzmu.

30 Dz.U. z 2020 r. poz. 1856 z późn. zm. Określa ona organy właściwe w sprawach zarządzania kryzysowego oraz ich zadania i zasady działania w tej dziedzinie, a także zasady finansowania zadań zarządzania kryzysowego.

31 Dz.U. z 2020 r. poz. 1444 z późn. zm. W kodeksie karnym oprócz definicji przestępstwa o charakterze terrorystycznym (art. $115 \S 20$ k.k.) przewidziane są różne przestępstwa związane z działalnością terrorystyczną, w szczególności: finansowanie przestępstwa o charakterze terrorystycznym (art. 165a), rozpowszechnianie treści mogących ułatwić popełnienie przestępstwa o charakterze terrorystycznym albo branie udziału w szkoleniu mogącym umożliwić popełnienie takiego przestępstwa (art. 255a), udział, zakładanie, kierowanie grupą lub związkiem o charakterze terrorystycznym (art. $258 \S 2$ i 4), przekroczenie granicy w celu popełnienia przestępstwa o charakterze terrorystycznym (art. 259a).

32 C. Nowak, Wplyw procesów globalizacyjnych na polskie prawo karne, Warszawa 2014, s. 320. Zob. także K. Wiak, Kryminalizacja finansowania terroryzmu w polskim prawie karnym, „Palestra” 2010, nr 7-8, s. 58. 
w polskim prawie karnym kryminalizowane były niejako ,przy okazji”, na podstawie bardziej uniwersalnych przepisów, to zasadniczo do 2004 roku polskie prawo karne nie zawierało regulacji nawiązujących bezpośrednio i konkretnie do terroryzmu ${ }^{33}$. Dopiero ustawą z dnia 16 kwietnia 2004 roku o zmianie ustawy - Kodeks karny oraz niektórych innych ustaw ${ }^{34}$ dodano bowiem do kodeksu karnego definicję przestępstwa o charakterze terrorystycznym (art. $115 \S 20$ k.k. ${ }^{35}$ ). Sama zaś kryminalizacja finansowania terroryzmu w polskim prawie karnym nastąpiła dosyć późno, bo dopiero 22 października 2009 roku, kiedy weszła w życie ustawa z dnia 25 czerwca 2009 roku o zmianie ustawy o przeciwdziałaniu wprowadzaniu do obrotu finansowego wartości majątkowych pochodzących $\mathrm{z}$ nielegalnych lub nieujawnionych źródeł oraz o przeciwdziałaniu finansowaniu terroryzmu oraz o zmianie niektórych innych ustaw ${ }^{36}$. Wskazaną nowelizacją dodano do kodeksu karnego przepis art. 165a typizujący przestępstwo finansowania terroryzmu, a także na podstawie ustawy o odpowiedzialności podmiotów zbiorowych za czyny zabronione pod groźbą kary (art. 16 ust. 1 pkt 12 u.o.p.z.) ${ }^{37}$ uzupełniono katalog przestępstw, których popełnienie przez osobę fizyczną może prowadzić do pociągnięcia podmiotu zbiorowego do odpowiedzialności, o przestępstwo stypizowane w przepisie art. 165a kodeksu karnego.

Celem tej nowelizacji było przede wszystkim dostosowanie przepisów polskiego prawa do międzynarodowej konwencji o zwalczaniu finansowania terroryzmu, przyjętej przez Zgromadzenie Ogólne Narodów Zjednoczonych 9 grudnia 1999 roku i ratyfikowanej przez Rzeczpospolitą Polską 9 stycznia 2003 roku $^{38}$,

33 S. Hoc, op. cit., s. 25.

34 Dz.U. Nr 93, poz. 889 z późn. zm.

35 Zgodnie z przepisem art. $115 \S 20$ kodeksu karnego przestępstwem o charakterze terrorystycznym jest czyn zabroniony zagrożony karą pozbawienia wolności, której górna granica wynosi co najmniej 5 lat, popełniony w celu: 1. poważnego zastraszenia wielu osób, 2. zmuszenia organu władzy publicznej Rzeczypospolitej Polskiej lub innego państwa albo organu organizacji międzynarodowej do podjęcia lub zaniechania określonych czynności, 3. wywołania poważnych zakłóceń w ustroju lub gospodarce Rzeczypospolitej Polskiej, innego państwa lub organizacji międzynarodowej, a także groźba popełnienia takiego czynu. Szerzej zob. R. Kokot, Uwagi o istocie przestępstwa o charakterze terrorystycznym i jego karaniu. Czesść I, „Nowa Kodyfikacja Prawa Karnego” 48, 2018, s. 31-46; idem, Uwagi o istocie przestepstwa o charakterze terrorystycznym i jego karaniu. Część II, „Nowa Kodyfikacja Prawa Karnego” 49, 2018, s. 13-27.

36 Dz.U. Nr 166, poz. 1317. Należy jednak zwrócić uwagę, że kryminalizacja finansowania przestępstwa o charakterze terrorystycznym przewidziana była już w rządowym projekcie ustawy o zmianie ustawy - Kodeks karny oraz niektórych innych ustaw (druk sejmowy nr 1756), przy czym ze względu na skrócenie kadencji parlamentu nie został on ostatecznie uchwalony. Zob. K. Wiak, op. cit., s. 57.

37 Ustawa z dnia 28 października 2002 roku o odpowiedzialności podmiotów zbiorowych za czyny zabronione pod groźbą kary (Dz.U. z 2020 r. poz. 358 z późn. zm.; dalej: u.o.p.z.).

38 Dz.U. Nr 44, poz. 374. W art. 2 wskazano, że przestępstwo w rozumieniu konwencji popełnia ten, kto jakimikolwiek środkami, bezpośrednio lub pośrednio, bezprawnie i umyślnie, udostępnia lub gromadzi fundusze z zamiarem ich wykorzystania, lub też mając świadomość, że zostaną one wykorzystane, w całości lub w części, do dokonania: 1. czynu stanowiącego przestępstwo 
a także dyrektywy 2005/60/WE Parlamentu Europejskiego i Rady z 26 października 2005 roku w sprawie przeciwdziałania korzystaniu z systemu finansowego $\mathrm{w}$ celu prania pieniędzy oraz finansowania terroryzmu ${ }^{39}$. Obowiązek kryminalizacji finansowania terroryzmu wynikał także $\mathrm{z}$ innych aktów o charakterze międzynarodowym ${ }^{40}$. Obecnie konieczność kryminalizacji w tym zakresie wynika również z dyrektywy Parlamentu Europejskiego i Rady (UE) 2017/541 z 15 marca 2017 roku w sprawie zwalczania terroryzmu i zastępującej decyzję ramową Rady 2002/475/WSiSW oraz zmieniającej decyzję Rady 2005/671/WSiSW ${ }^{41}$. Zgodnie z art. 11 wskazanej dyrektywy na państwach członkowskich spoczywa obowiązek kryminalizacji umyślnych działań polegających na dostarczaniu lub gromadzeniu funduszy z zamiarem ich wykorzystania lub ze świadomością, że mają zostać wykorzystane, w całości lub w części, do popełnienia lub do przyczynienia się do popełnienia przestępstw określonych art. 3-10 dyrektywy ${ }^{42}$.

Wedle pierwotnego brzmienia przepisu art. 165a kodeksu karnego kryminalizacji podlegało umyślne gromadzenie, przekazywanie lub oferowanie środków płatniczych, instrumentów finansowych, papierów wartościowych, wartości dewizowych, praw majątkowych lub innego mienia ruchomego lub nieruchomości w zamiarze sfinansowania przestępstwa o charakterze terrorystycznym albo udostępnienia ich zorganizowanej grupie lub związkowi mającym na celu popełnienie takiego przestępstwa lub osobie biorącej udział w takiej grupie lub związku. Przestępstwo to zagrożone było karą pozbawienia wolności od 2 do 12 lat. Następnie ustawą z 9 października 2015 roku o zmianie ustawy — Kodeks karny

określone definicją zawartą $\mathrm{w}$ jednym $\mathrm{z}$ traktatów wymienionych $\mathrm{w}$ aneksie; 2. czynu mającego spowodować śmierć lub ciężki uszczerbek na zdrowiu osoby cywilnej lub innej osoby nieuczestniczącej aktywnie w działaniach wojennych w sytuacji konfliktu zbrojnego, jeśli celem takiego czynu, wynikającym bądź z jego charakteru, bądź z kontekstu, w jakim jest popełniony, jest zastraszenie ludności albo skłonienie rządu lub organizacji międzynarodowej do dokonania lub do zaniechania określonej czynności. Z kolei w art. 5 konwencji nałożono na jej państwa-strony między innymi obowiązek zastosowania skutecznych i proporcjonalnych sankcji karnych wobec osób prawnych.

39 Dz.Urz. UE seria L Nr 309, s. 15. W art. 1 dyrektywy nałożono na państwa członkowskie między innymi zakaz finansowania terroryzmu, który dla celów dyrektywy oznacza bezpośrednie lub pośrednie dostarczanie lub gromadzenie funduszy wszelkimi sposobami, z zamiarem ich użycia lub ze świadomością, że mają zostać użyte, w całości lub w części, w celu popełnienia któregokolwiek z przestępstw określonych w art. 1-4 decyzji ramowej Rady 2002/475/WSiSW z dnia 13 czerwca 2002 roku w sprawie zwalczania terroryzmu (Dz.Urz. UE seria L Nr 164, s. 3). Natomiast $\mathrm{w}$ art. 39 dyrektywy nałożono obowiązek wprowadzenia skutecznych, proporcjonalnych i odstraszających sankcji na osoby fizyczne i prawne z tytułu naruszenia przepisów krajowych przyjętych zgodnie $\mathrm{z}$ dyrektywą.

40 K. Wiak, op. cit., s. 58.

41 Dz.Urz. UE seria L 88, s. 6.

42 Jeżeli natomiast finansowanie terroryzmu dotyczy któregokolwiek z przestępstw, które wymieniono w art. 3, 4 lub 9 dyrektywy, nie jest konieczne, aby doszło do faktycznego wykorzystania tych funduszy do popełnienia lub do przyczynienia się do popełnienia jednego z tych przestępstw, ani nie jest konieczne, by sprawca wiedział, na potrzeby którego konkretnego przestępstwa lub przestępstw fundusze te mają być wykorzystane. 
oraz niektórych innych ustaw ${ }^{43}$ poszerzono zakres finansowania terroryzmu poprzez zmianę brzmienia przepisu art. 165a kodeksu karnego na następujące:

Kto gromadzi, przekazuje lub oferuje środki płatnicze, instrumenty finansowe, papiery wartościowe, wartości dewizowe, prawa majątkowe lub inne mienie ruchome lub nieruchomości w zamiarze sfinansowania przestępstwa o charakterze terrorystycznym albo udostępnienia ich zorganizowanej grupie lub związkowi mającym na celu popełnienie takiego przestępstwa lub osobie biorącej udział w takiej grupie lub związku, podlega karze pozbawienia wolności od lat 2 do 12 .

W uzasadnieniu projektu przedmiotowej ustawy wskazano, że

Celem ustawy jest wykonanie międzynarodowych zobowiązań Polski w zakresie prawa karnego wynikających z członkostwa w Radzie Europy i Unii Europejskiej. W zakresie prawa Rady Europy projekt nowelizuje przepisy Kodeksu karnego przewidujące karalność prania brudnych pieniędzy i finansowania terroryzmu. Potrzeba tych zmian wynika z konieczności implementacji niektórych zaleceń komitetu Moneyval Rady Europy, zajmującego się tą problematyką ${ }^{44}$.

Zgodnie z deklaracją projektodawcy celem rekomendacji Moneyval było przede wszystkim ,,pozbawienie przestępstwa finansowania terroryzmu charakteru kierunkowego oraz penalizacja przekazania środków organizacji terrorystycznej lub terroryście w jakimkolwiek celu"45.

Wreszcie ustawą z dnia 23 marca 2017 roku o zmianie ustawy - Kodeks karny oraz niektórych innych ustaw $^{46}$ dokonano kolejnej modyfikacji zakresu kryminalizacji finansowania terroryzmu (art. 165a k.k.). Celem takiego zabiegu legislacyjnego miało być

zapobieganie sytuacjom, w których zamiarem sprawcy nie jest objęte sfinansowanie konkretnego czynu terrorystycznego, osoby lub grupy osób (terrorystów), jednakże znane sprawcy okoliczności wskazują, iż takie przeznaczenie gromadzonego, przekazywanego lub oferowanego przezeń mienia jest wysoce prawdopodobne. Podejrzenie przestępnego przeznaczenia mienia musi przy tym wynikać z pewnego ciągu informacji, który, przy pomocy zasad logicznego rozumowania, pozwala założyć wykorzystanie mienia w celu wsparcia działalności terrorystycznej. Nie może się natomiast opierać jedynie na domysłach, pogłoskach lub stereo$\operatorname{typach}^{47}$.

Wskazana nowelizacja zdeterminowała kształt kryminalizacji finansowania terroryzmu w polskim prawie karnym, która będzie stanowić przedmiot rozważań w części drugiej niniejszego tekstu.

43 Dz.U. z 2015 r. poz. 1855.

44 Uzasadnienie rządowego projektu ustawy o zmianie ustawy — Kodeks karny oraz niektórych innych ustaw, druk sejmowy nr 3659, s. 1 .

45 Ibidem, s. 2.

46 Dz.U. poz. 768.

47 Uzasadnienie rządowego projektu ustawy o zmianie ustawy - Kodeks karny oraz niektórych innych ustaw, druk sejmowy nr 1186, s. 37. 


\section{Bibliografia}

Dadak W., Terroryzm - nowe zagrożenie czy niedostrzegane wcześniej zjawisko? O problemach $z$ definiowaniem i analiza przestępczości terrorystycznej, [w:] W poszukiwaniu prawdy. Rozważania o prawdzie, historii i sprawiedliwości. Prace dedykowane profesorowi Janowi Widackiemu, red. K. Banasik, A Kargol, A. Kubiak-Cyrul, M. Lubelski, E. Plebanek, J. Strzelec, Kraków 2018.

Europol, European Union Terrorism Situation and Trend Report, Luxemburg 2021.

Fletcher G.P., The Indefinable Concept of Terrorism, „Journal of International Criminal Justice” 4, 2006, nr 5.

Gibbs J.P., Conceptualization of Terrorism, „American Sociological Review” 54, 1989, nr 3.

Guzik-Makaruk E.M., Zatyka E., Rada Europy wobec terroryzmu - elementy strategii przeciwdziatania, „Białostockie Studia Prawnicze” 2009, z. 6.

Hoc S., Kryminalizowanie finansowania terroryzmu, „Opolskie Studia Administracyjno-Prawne” 14, 2016, nr 1.

Hołyst B., Terroryzm, t. 1, Warszawa 2000.

Indecki K., Prawo karne wobec terroryzmu i aktu terrorystycznego, Łódź 1998.

Kokot R., Uwagi o istocie przestępstwa o charakterze terrorystycznym i jego karaniu. Część I, „Nowa Kodyfikacja Prawa Karnego” 48, 2018.

Kokot R., Uwagi o istocie przestępstwa o charakterze terrorystycznym i jego karaniu. Część II, „Nowa Kodyfikacja Prawa Karnego” 49, 2018.

Nowak C., Wptyw procesów globalizacyjnych na polskie prawo karne, Warszawa 2014.

Ochman P., Baściuk J., Niepostuszeństwo obywatelskie a polski system prawa karnego, [w:] Prawna działalność instytucji społeczeństwa obywatelskiego, red. J. Blicharz, J. Boć, Wrocław 2009.

Pikulski S., Prawne środki zwalczania terroryzmu, Olsztyn 2000.

Prawo karne międzynarodowe, red. L. Gardocki, Warszawa 2017.

Resztak I., Konwencje Rady Europy o przeciwdziałaniu zjawisku terroryzmu, „Prokuratura i Prawo” 2012, nr 10.

Resztak I., Zjawisko terroryzmu, „Prokuratura i Prawo” 2012, nr 7-8.

Sprawozdanie Generalnego Inspektora Informacji Finansowej z realizacji ustawy z dnia 1 marca 2018 roku o przeciwdziałaniu praniu pieniędzy oraz finansowaniu terroryzmu w 2020 roku, Warszawa 2021.

Terroryzm. Materia ustawowa?, red. K. Indecki, P. Potejko, Warszawa 2009.

Uzasadnienie rządowego projektu ustawy o działaniach antyterrorystycznych oraz o zmianie niektórych innych ustaw, druk sejmowy nr 516.

Uzasadnienie rządowego projektu ustawy o zmianie ustawy — Kodeks karny oraz niektórych innych ustaw, druk sejmowy nr 1186.

Uzasadnienie rządowego projektu ustawy o zmianie ustawy - Kodeks karny oraz niektórych innych ustaw, druk sejmowy nr 3659.

Wiak K., Kryminalizacja finansowania terroryzmu w polskim prawie karnym, „Palestra” 2010, nr 7-8.

Wilkinson P., Terrorism versus Democracy: The Liberal State Sesponse, Abingdon 2005. 